\title{
COMPARISON OF DATA MINING CLASSIFICATION ALGORITHM FOR PREDICTING THE PERFORMANCE OF HIGH SCHOOL STUDENTS
}

\author{
Tiska Pattiasina1; Didi Rosiyadi² \\ 1,2 Masters in Computer Science \\ STMIK Nusa Mandiri Jakarta, Indonesia \\ 1elleoratiska07@gmail.com, ${ }^{2}$ didi.rosiyadi@gmail.com
}

\begin{abstract}
Data Mining is a series of processes to explore added value in the form of unknown information manually from the database. In the world of data mining education can be used to obtain information about student performance. In this study the researchers took research samples from class XI (eleven) students at SMAN 3 Ambon by classifying student performance based on thirteen attributes, namely: age, sex, school organization, extracurricular activities, pocket money, duration of study at home, duration of social media, online game duration, attendance, illness, permits, semester 1 and semester 2 grades. Using the KDD (Knowledge Discovery Database) method and classification algorithm that will be used, namely, decision tree, Naïve Bayes and K-Nearest Neighbor. And then do the test using $k$-fold cross validation.
\end{abstract}

Essence - In the world of data mining education can be utilized to obtain student performance information. This research presents the results of new decision making using data mining techniques. This study aims to compare the Decision Tree, Naive Bayes, and k-Nearets Neighbor ( $k-N N)$ algorithms to improve accuracy in student performance at Ambon State High School 3. And the research method used is the classification method by comparing two algorithms, Naive Bayes and K-nearest neighbor. In this research, the highest accuracy is obtained in the Decision Tree algorithm, which is $99.6047 \%$.

Keywords: Data mining, classification, Decision Tree, Naive Bayes, KNN.

\section{INTRODUCTION}

Data Mining is the extraction of important or interesting information or patterns from existing data in a large database (Siregar \& Pusphabuana, 2017). And data mining is a mixture of statistics, artificial intelligence, and database research that is still developing (Gorunescu, 2011). Education Data Mining also referred to as EDM is defined as a field of scientific inquiry centered around developing methods to make discoveries in unique types of data that originate from educational settings, and use these methods to better understand students and the settings they learn (Peterson, Penelope L; Baker, Eva ; McGaw, 2010)

In the world of education research using data mining has been carried out by several researchers to provide increased excellence in higher education, which creates human resources is an ongoing subject. Therefore, the prediction of high school level student performance is very important for continuing education, because the quality of the teaching process can be provided according to student needs. In this case the data and information collected to be able to maintain the quality of students.

Some research in the world of education has been carried out, namely the first research Prediction of Student Performance Using Decision Tree C 4.5 Algorithm, the study aims to predict student achievement based on parents' socioeconomic status, student discipline and student achievement using data mining methods with the Decision Tree, CHAID, Regression algorithm Multiple. Research subjects were students at SD Negeri 4 Trimuloyo. after recording data obtained 352record. Based on data analysis using a decision tree, data mining to predict student achievement based on the socioeconomic status of parents, student discipline and student achievement using data mining methods obtained the following results: economic variables are variables that determine the potential for student success. or not learn achievements in the future. This is evidenced by the variables that become the root node in the decision tree formed. Student achievement variable, is the second important variable in the success of student studies. This shows that aspects of students' knowledge or intelligence are very influential on the success of their learning. Conversely, even though students have less predictable knowledge, high willpower can still be achieved at least in the b or c category. The average $\mathrm{C} 4.5$ success algorithm in carrying out classification data reaches $99.43 \%$ in accuracy. This shows that this algorithm has a reliable performance in doing classification (Kuntoro \& Sudarwanto, 2017)

The second study with the title using data mining to predict secondary school student 
performance, the beginning of this study discusses the level of education of the Portuguese population which has increased in the last decade but it turns out statistical results make Portugal remain at the tail end of Europe because of the high rate of student failure. In particular, the lack of success in the Mathematics and Potugic core classes is very serious. On the other hand, the field of Business Intelligence (BI) or / Data Mining (DM), which aims to extract high-level knowledge from raw data, offers interesting algorithmic automation that can help the education field. This study aims to approach student achievement in secondary education using the BI or / Data Mining technique. Current real-world data (eg student grades, demographics, social and school features) are collected using school reports and questionnaires. Two core classes (ie Mathematics and Portuguese) are modeled under binary / five-level classification and regression tasks. Also, four DM models (namely Decision Tree, Random Forest, Neural Network and Support Vector Machine) and three input choices (for example with and without previous values) are tested. The results show that good predictive accuracy can be achieved, provided the grades for the first and / or second school periods are available. Although student performance has been strongly influenced by past evaluations, explanatory analysis has shown that there are also other relevant features such as the amount of absenteeism, work and parental education, alcohol consumption (Cortez \& Silva, 2008).

The third study, entitled the K-Nearest Neighbor (k-NN) Algorithm Model For Student Graduation Prediction, predicting the rise in the ability of students to complete studies on time is one element of university accreditation assessment This research was conducted to predict student graduation using data mining classifications with processing student data obtained from 1633 student databases, with attributes nim, name, age, faculty, semester 1 to IP semester 8 using the K-Nearest Neighbor algorithm by clustering data $\mathrm{k}=1, \mathrm{k}-2, \mathrm{k}-3, \mathrm{k}=4$, and $\mathrm{k}=5$ (Rohman, 2015).

In this study the researchers took a sample of research from class XI students of SMA Negeri 3 Ambon by classifying student learning outcomes based on age, organization and extracurricular activities followed by school students, pocket money earned by students from parents, duration or the amount of time students used to study, social media, play online games, attendance, permits and illness during 2 semesters, average semester 1 and 2. Using the KDD (Knowledge Discovery Database) method and classification algorithm to be used, namely Decision Tree, Naïve Bayes and K-Nearest Neighbor use weka tools. And then testing is done using $\mathrm{k}$-fold cross validation, then evaluating and validating with a confusion matrix, precision, recall, ROC.

The study aims to compare the Decision Tree, Naive Bayes, and k-Nearets Neighbor (k-NN) algorithms to improve accuracy in student performance at Ambon State High School 3.

\section{MATERIALS AND METHODS}

\section{A. Datasets}

The data used in this research is real-world data collected from class XI report cards (eleven) with a total of 253 students and questionnaire results that have been filled out by students of SMA Negeri 3 Ambon. Data taken in the form of name, class, age, gender, organization at school, extracurricular, pocket money, duration of study, duration of social media, duration of online games, information on attendance, illness, permission, semester value 1 , semester value 2 and label sample raw data can be seen in table 1 . The data consists of two labels namely; Very Good (A) with a total of 81 and Good (B) with a total of 172 .

Table 1. Data SMA Negeri 3 Ambon

\begin{tabular}{|c|c|c|c|c|c|c|c|c|c|c|c|c|c|c|c|}
\hline No & Name & Age & Gen & $\begin{array}{l}\text { School } \\
\text { organization }\end{array}$ & $\begin{array}{l}\text { Extra- } \\
\text { curricular }\end{array}$ & $\begin{array}{l}\text { Pocket } \\
\text { money }\end{array}$ & $\begin{array}{l}\text { Duration } \\
\text { of study } \\
\text { at home }\end{array}$ & $\begin{array}{l}\text { Social } \\
\text { media } \\
\text { duration }\end{array}$ & $\begin{array}{l}\text { Duration } \\
\text { of online } \\
\text { games }\end{array}$ & $\begin{array}{l}\text { Total } \\
\text { present }\end{array}$ & $\begin{array}{l}\text { Total } \\
\text { sick }\end{array}$ & $\begin{array}{l}\text { Tot } \\
\text { Permi- } \\
\text { ssion }\end{array}$ & $\begin{array}{l}\text { Sem } \\
=1\end{array}$ & $\begin{array}{l}\text { Sem } \\
=2\end{array}$ & $\mathrm{~L}$ \\
\hline 1 & $\begin{array}{l}\text { Dini Erna } \\
\text { Karlina }\end{array}$ & 15 & 2 & 2 & 1 & 15000 & 3 & 2 & 2 & 240 & 0 & 0 & 85 & 86 & B \\
\hline 2 & Shanty & 14 & 2 & 2 & 2 & 35000 & 2 & 3 & 0 & 237 & 3 & 0 & 81 & 81 & B \\
\hline 3 & $\begin{array}{l}\text { Muhammad } \\
\text { Joseph }\end{array}$ & 14 & 1 & 2 & 2 & 20000 & 1 & 4 & 1 & 240 & 0 & 0 & 81 & 81 & B \\
\hline 4 & $\begin{array}{l}\text { Fatahilah } \\
\text { Bayu }\end{array}$ & 16 & 1 & 2 & 1 & 15000 & 1 & 1 & 1 & 240 & 0 & 0 & 85 & 86 & B \\
\hline 5 & Akmal A & 15 & 1 & 2 & 1 & 10000 & 1 & 2 & 2 & 240 & 0 & 0 & 80 & 81 & B \\
\hline 6 & Taftaniza & 16 & 2 & 1 & 2 & 12000 & 4 & 1 & 2 & 236 & 4 & 0 & 83 & 84 & B \\
\hline 7 & Giansun & 15 & 2 & 2 & 1 & 20000 & 1 & 3 & 0 & 237 & 2 & 1 & 80 & 83 & B \\
\hline 8 & Mirna & 16 & 2 & 2 & 2 & 10000 & 1 & 2 & 0 & 240 & 0 & 0 & 81 & 82 & B \\
\hline
\end{tabular}




\begin{tabular}{|c|c|c|c|c|c|c|c|c|c|c|c|c|c|c|c|}
\hline 9 & Ananda & 15 & 1 & 1 & 1 & 15000 & 2 & 2 & 2 & 237 & 2 & 1 & 80 & 80 & $\bar{B}$ \\
\hline 10 & $\begin{array}{l}\text { Ilhamni } \\
\text { Zein }\end{array}$ & 15 & 2 & 2 & 2 & 50000 & 3 & 2 & 0 & 240 & 0 & 0 & 91 & 92 & A \\
\hline 11 & M Rival & 16 & 1 & 1 & 2 & 30000 & 1 & 1 & 1 & 240 & 0 & 0 & 81 & 81 & B \\
\hline 12 & $\begin{array}{l}\text { Nissaeryn Z } \\
\text { Umayyah }\end{array}$ & 15 & 2 & 2 & 1 & 15000 & 2 & 2 & 0 & 240 & 0 & 0 & 91 & 91 & A \\
\hline 13 & Novita & 15 & 2 & 2 & 2 & 25000 & 2 & 0 & 0 & 240 & 0 & 0 & 91 & 92 & A \\
\hline 14 & Giannisa R & 16 & 2 & 2 & 2 & 20000 & 2 & 1 & 0 & 240 & 0 & 0 & 81 & 82 & B \\
\hline 15 & Safni Tuara & 16 & 2 & 1 & 2 & 20000 & 2 & 1 & 0 & 240 & 0 & 0 & 81 & 82 & B \\
\hline 16 & $\begin{array}{l}\text { Veni } \\
\text { Armianti }\end{array}$ & 15 & 2 & 2 & 2 & 20000 & 1 & 2 & 3 & 240 & 0 & 0 & 91 & 92 & A \\
\hline 17 & $\begin{array}{l}\text { Juenda } \\
\text { Anaci }\end{array}$ & 15 & 2 & 2 & 2 & 15000 & 1 & 2 & 0 & 240 & 0 & 0 & 81 & 83 & B \\
\hline 18 & $\begin{array}{l}\text { Aldo } \\
\text { Sahetapy }\end{array}$ & 15 & 1 & 2 & 1 & 15000 & 2 & 1 & 1 & 240 & 0 & 0 & 81 & 82 & B \\
\hline 19 & $\begin{array}{l}\text { Roy A } \\
\text { Souhoka }\end{array}$ & 16 & 1 & 2 & 1 & 25000 & 1 & 2 & 2 & 240 & 0 & 0 & 83 & 84 & B \\
\hline 20 & $\begin{array}{l}\text { Michelle } \\
\text { Manane }\end{array}$ & 15 & 2 & 1 & 1 & 35000 & 2 & 1 & 0 & 240 & 0 & 0 & 80 & 81 & B \\
\hline$\ldots$ & $\ldots$ & $\ldots$ & $\ldots$ & $\cdots$ & $\ldots$ & $\cdots$ & $\ldots$ & $\ldots$ & $\ldots$ & $\ldots$ & $\ldots$ & $\ldots$ & $\ldots$ & $\ldots$ & $\ldots$ \\
\hline 253 & $\begin{array}{l}\text { Estrella L } \\
\text { Mararessy }\end{array}$ & 15 & 2 & 2 & 2 & 15000 & 2 & 2 & 0 & 240 & 0 & 0 & 70 & 76 & B \\
\hline
\end{tabular}

Source : (Pattiasina \& Rosiyadi, 2020)

Following are the attributes that are inputted on the Weka tools can be seen in Figure 1.

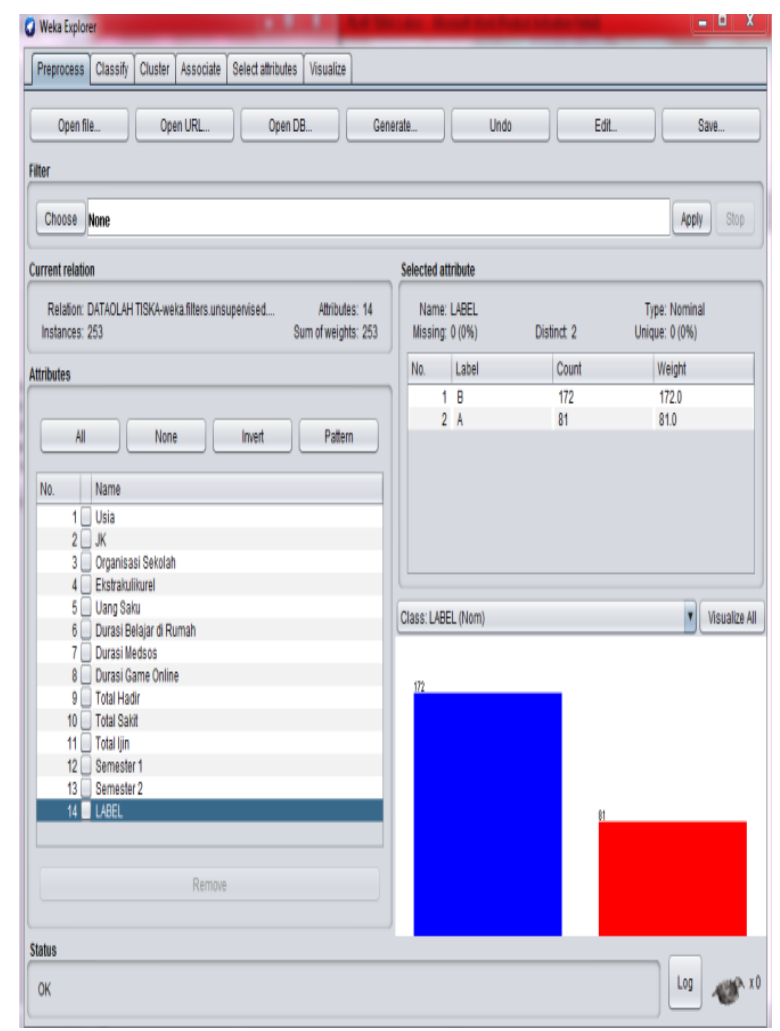

Source: (Pattiasina \& Rosiyadi,2020)

Figure 1. Dataset in Weka Tools

\section{B. Method}

This study is to classify the learning outcomes of class XI (eleven) students with the research methodology used in this study is to use the Knowledge Discovery in Database (KDD) method consisting of 5 stages: (Sugianto, 2015):

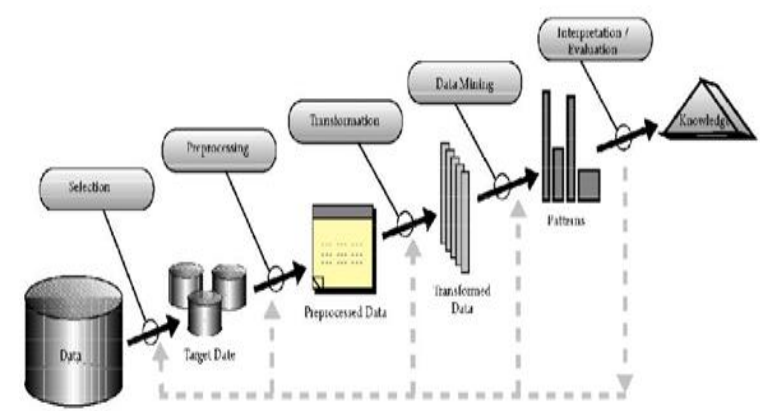

Source : (Sugianto, 2015)

Figure 2. Research Methods

1. Determine the target data which includes data selection and focus more on the subset of data.

2. Cleaning and integration, for data cleaning, which removes noise and inconsistent data, while Integration is combining data from a variety of different sources.

3. Selection and transformation, in data selection that is taking data in accordance with the task of analysis from the database, while Data transformation, which combines data into a form or model suitable for excavation through summary or aggregation operations.

4. Data mining is an important and primary process for extracting patterns from data with more recent methods.

5. Pattern evaluation, which identifies interesting patterns and represents knowledge based on interestingness measures.

6. Knowledge presentation, in the form of presentation of knowledge that is extracted and presented to users using visualization and 
knowledge representation techniques (Sugianto, 2015).

Then the research steps that will be carried out can be seen in the picture below:

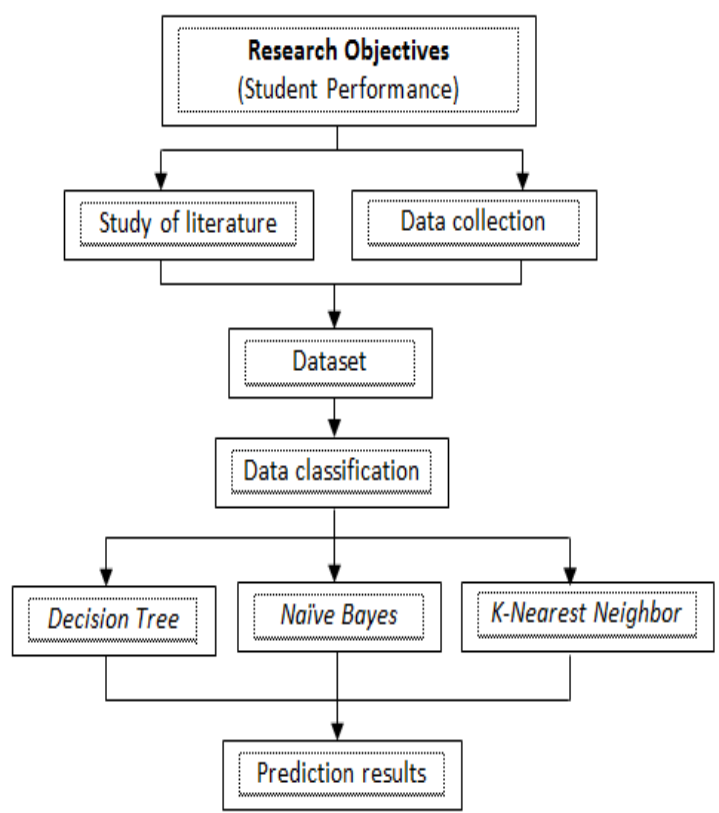

Source: (Pattiasina \& Rosiyadi,2020)

Figure 3. Research steps

In the research steps above can be explained as follows:

a. In accordance with the objectives of the study, which is to implement and compare the Decision Tree, Naïve Bayes and K-Nearest Neighbor algorithms to improve accuracy in student performance at Ambon 3 High Schools.

b. Then do a search of data to the curriculum section of Ambon 3 High School as data to be processed and look for literature studies that are in accordance with research.

c. Data obtained from the curriculum is then processed using the classification method with the Decision Tree algorithm, naive bayes and knearest neighbor.

d. Data were tested using validation to get the best accuracy from the algorithm.

e. The results of the algorithm are compared in order to get the best algorithm results, which will be used as a reference in knowing student learning outcomes.

The results of the implementation of the data classification are evaluated and validated so that it can be known how accurate the prediction results will be. Evaluation and validation can be done using confunsion matrix and receiver operating characteristics (ROC).

Confusion matrix is a method used to calculate accuracy in the concept of data mining.
Evaluation with confunsion matrix produces accuracy, precision, and recall values. Accuracy in classification is the presentation of the accuracy of data records that are classified correctly after testing the classification results. Precision or confidence is the proportion of positively predicted mattresses that is also positive true to the actual data. Recall or sensitivity is the proportion of positive cases that are actually correctly predicted correctly (Hand, 2007). This method uses a matrix table as in table 3.

Table 2. Confusion Matrix Model

\begin{tabular}{ccc}
\hline Class Pred & \multicolumn{2}{c}{ Actual } \\
\cline { 2 - 3 } & + & - \\
\hline+ & True positive(A) & False negative(B) \\
\hline- & False positive(C) & True negative(D) \\
\hline Source: (Hand, 2007)
\end{tabular}

The ROC (Receiver Operating Characteristic) curve is another way to evaluate the accuracy of the classification visually (Gorunescu, 2011). The accuracy can be diagnosed as follows:

Accuracy $0.90-1.00=$ Excellent classification Accuracy $0.80-0.90=$ Good classification Accuracy $0.70-0.80=$ Fair classification Accuracy $0.60-0.70=$ Poor classification Accuracy $0.50-0.60=$ Failure

\section{RESULTS AND DISCUSSION}

Classification is done to discuss the performance of high school students using weka with the decision tree algorithm, naive bayes, knearest neighbor. The classification test is shown by cross validation using 10 fold.

\section{A. Decision Tree}

Decision Tree can be seen from the probability that will affect student performance. In the Decision Tree the data is expressed in tabular form with attributes and records. Decision tree process flow is to change the form of table data into a model tree, change the tree into a rule and simplify it. The decision tree algorithm stages are; prepare training data, determine roots and trees, calculate the gain value. The results can be seen in table 3 .

Table 3. Entrophy and gain values

\begin{tabular}{lrrrrr}
\hline The Knot & \multicolumn{1}{l}{ B } & \multicolumn{1}{c}{ A } & ENTROPY & GAIN \\
\hline TOTAL & 253 & 172 & 81 & 0.90455330 & \\
Age & & & & & 1.7544107 \\
14 Year & 7 & 6 & 1 & 0.59167277 & \\
15 Year & 120 & 85 & 35 & 0.87086446 & \\
16 Year & 114 & 73 & 41 & 0.94239154 & \\
17 Year & 10 & 8 & 2 & 0.72192809 & \\
\hline
\end{tabular}




\begin{tabular}{|c|c|c|c|c|c|}
\hline \multirow{2}{*}{$\begin{array}{c}\text { The Knot } \\
18 \text { Year }\end{array}$} & \multicolumn{2}{|r|}{$\mathbf{B}$} & \multirow{2}{*}{$\frac{\mathrm{A}}{2}$} & \multirow{2}{*}{$\begin{array}{r}\text { ENTROPY } \\
0\end{array}$} & \multirow[t]{2}{*}{ GAIN } \\
\hline & 2 & 0 & & & \\
\hline total & 253 & 172 & 81 & & \\
\hline Gender & & & & & 1.0682747 \\
\hline 1. Man & 102 & 68 & 34 & 0.91829583 & \\
\hline 2. Woman & 151 & 104 & 47 & 0.89462059 & \\
\hline total & 253 & 172 & 81 & & \\
\hline \multicolumn{2}{|c|}{ School organization } & & & & 1.5041040 \\
\hline 1 Yes & 42 & 28 & 14 & 0.91829583 & \\
\hline 2. No & 211 & 144 & 67 & 0.90168129 & \\
\hline Total & 253 & 172 & 81 & & \\
\hline \multicolumn{2}{|c|}{ Extracurricular } & & & & 1.3034146 \\
\hline 1 Yes & 72 & 50 & 22 & 0.88797632 & \\
\hline 2. No & 181 & 122 & 59 & 0.91075254 & \\
\hline Total & 253 & 172 & 81 & & \\
\hline Pocket mone & & & & & 1.1154092 \\
\hline $\begin{array}{l}5000- \\
10.000\end{array}$ & 91 & 57 & 34 & 0.95341587 & \\
\hline $\begin{array}{l}11.000- \\
20.000\end{array}$ & 122 & 89 & 33 & 0.84216948 & \\
\hline 21.000 up & 40 & 26 & 14 & 0.93406805 & \\
\hline Total & 253 & 172 & 81 & & \\
\hline \multicolumn{3}{|c|}{ Duration of study at home } & & & 1.0789076 \\
\hline 1 Hour & 100 & 68 & 32 & 0.90438148 & \\
\hline 2 Hour & 115 & 82 & 33 & 0.86475726 & \\
\hline 3 Hour & 25 & 12 & 13 & 0.99884556 & \\
\hline 4 Hour & 13 & 10 & 3 & 0.77934987 & \\
\hline Total & 253 & 172 & 81 & & \\
\hline \multicolumn{3}{|c|}{ Social media duration } & & & 1.7335611 \\
\hline No & 9 & 5 & 4 & 0.99107606 & \\
\hline 1 Hour & 89 & 61 & 28 & 0.89841977 & \\
\hline 2 Hour & 84 & 59 & 25 & 0.87836099 & \\
\hline 3 Hour & 39 & 24 & 15 & 0.96123665 & \\
\hline 4 Hour & 32 & 23 & 9 & 0.85714847 & \\
\hline Total & 253 & 172 & 81 & & \\
\hline \multicolumn{3}{|c|}{ Duration of game online } & & & 0.7057835 \\
\hline No & 151 & 105 & 46 & 0.88688405 & \\
\hline 1 Hour & 48 & 33 & 15 & 0.89603823 & \\
\hline 2 Hour & 38 & 30 & 8 & 0.74248757 & \\
\hline 3 Hour & 9 & 3 & 6 & 0.91829583 & \\
\hline 4 Hour & 7 & 1 & 6 & 0.59167279 & \\
\hline Total & 253 & 172 & 81 & & \\
\hline Total present & & & & & 1.77582 \\
\hline $227-231$ & 3 & 2 & 1 & 0.91829583 & \\
\hline $232-236$ & 12 & 11 & 1 & 0.41381685 & \\
\hline $237-241$ & 238 & 159 & 79 & 0.91688890 & \\
\hline total & 253 & 172 & 81 & & \\
\hline
\end{tabular}

\begin{tabular}{|c|c|c|c|c|c|}
\hline \multicolumn{2}{|l|}{ The Knot } & \multirow[t]{2}{*}{ B } & \multirow[t]{2}{*}{$\mathbf{A}$} & \multirow[t]{2}{*}{ ENTROPY } & \multirow{2}{*}{$\begin{array}{l}\text { GAIN } \\
0.0066497\end{array}$} \\
\hline Total sick & & & & & \\
\hline $0-4$ & 250 & 169 & 81 & 0.90867838 & \\
\hline $5-9$ & 3 & 3 & 0 & 0 & \\
\hline Total & 253 & 172 & 81 & & \\
\hline \multicolumn{2}{|c|}{ Total permission } & & & & 0.0065187 \\
\hline $0-6$ Kali & 252 & 172 & 80 & 0.901598235 & \\
\hline 7 - 13 kali & 1 & 0 & 1 & 0 & \\
\hline total & 253 & 172 & 81 & & \\
\hline \multicolumn{2}{|c|}{ Semester 1 grades } & & & & 1.5505393 \\
\hline $70-79$ & 40 & 40 & 0 & 0 & \\
\hline $80-89$ & 187 & 132 & 55 & 0.873981048 & \\
\hline $90-100$ & 26 & 0 & 26 & 0 & \\
\hline Total & 253 & 172 & 81 & & \\
\hline \multicolumn{2}{|c|}{ Semester 2 grades } & & & & 1.5183595 \\
\hline $70-79$ & 13 & 13 & 0 & 0 & \\
\hline $80-89$ & 204 & 159 & 45 & 0.76124015 & \\
\hline $90-100$ & 36 & 0 & 36 & 0 & \\
\hline Total & 253 & 172 & 81 & & \\
\hline
\end{tabular}

Source: (Pattiasina \& Rosiyadi,2020)

As can be seen in table 3 that the attribute with the highest gain value is the total present which is 1.77582 , then the total present becomes the root node. The following accuracy results can be seen in Figure 4, using the Weka tools with J48 decision tree algorithm.

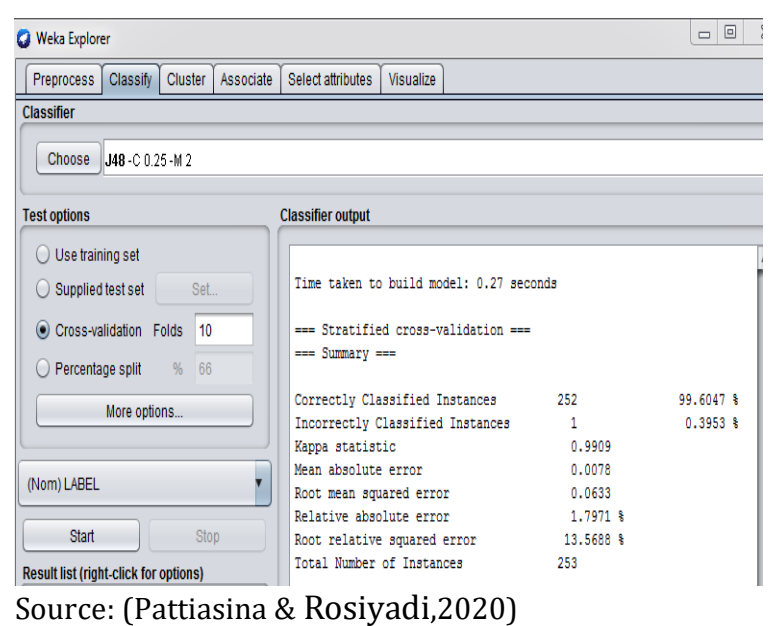

Figure 4. Accuracy results on weka tools

In figure 4 the accuracy in $\mathrm{j} 48$ is 99.6047 , the configuration matrix can be seen in table 4 .

\begin{tabular}{cccc}
\multicolumn{4}{c}{ Table 4. Configuration matrix results } \\
\hline & True B & True A & $\begin{array}{c}\text { Class } \\
\text { Pecission }\end{array}$ \\
\hline Pred. $B$ & 171 & 1 & $100 \%$ \\
Pred. $A$ & 0 & 81 & $98.80 \%$ \\
Class recall & $99.40 \%$ & $100 \%$ & \\
\hline
\end{tabular}

Source: (Pattiasina \& Rosiyadi,2020) 
Following are the results of the ROC graph on the $\mathrm{J} 48$ decision tree algorithm in the Weka tools can be seen in Figure 5.

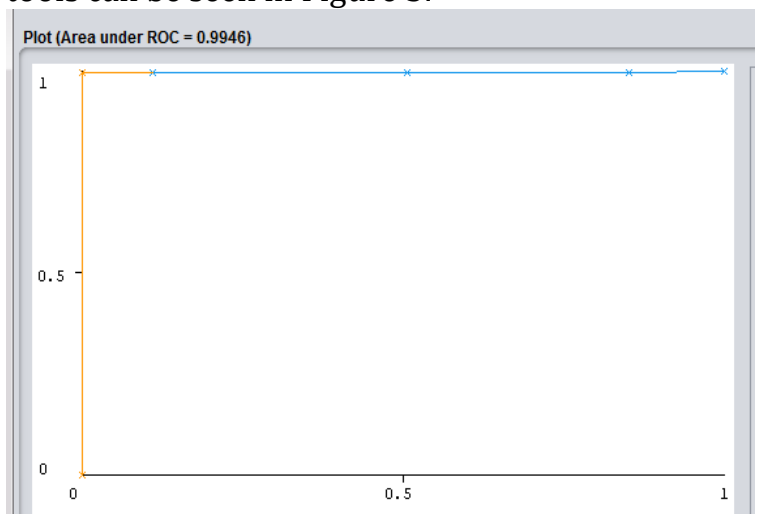

Source: (Pattiasina \& Rosiyadi,2020)

Figure 5. ROC results from decision tree j48

The results of ROC processing for $\mathrm{j} 48$ decision tree algorithm is 0.9946 with a diagnosis level of Excellent classification.

\section{B. Naive Bayes}

The following classification results using Naive Bayes can be seen in Table 5 using Weka tools with Naive Bayes algorithm.

Table 5. Results of the Naive Bayes classification

\begin{tabular}{|c|c|c|}
\hline \multirow[t]{3}{*}{ Attribute } & \multicolumn{2}{|c|}{ Class } \\
\hline & $\mathbf{B}$ & $\mathbf{A}$ \\
\hline & $(0.68)$ & $(0.32)$ \\
\hline \multicolumn{3}{|l|}{ Age } \\
\hline Mean & 15.4826 & 15.6173 \\
\hline std. dev. & 0.6423 & 0.6771 \\
\hline weight sum & 172 & 81 \\
\hline Precision & 1 & 1 \\
\hline \multicolumn{3}{|l|}{ Gender } \\
\hline Mean & 1.6047 & 1.5802 \\
\hline std. dev. & 0.4889 & 0.4935 \\
\hline weight sum & 172 & 81 \\
\hline Precision & 1 & 1 \\
\hline \multicolumn{3}{|l|}{ School organization } \\
\hline Mean & 1.8372 & 1.8272 \\
\hline std. dev. & 0.3692 & 0.3781 \\
\hline weight sum & 172 & 81 \\
\hline Precision & 1 & 1 \\
\hline \multicolumn{3}{|l|}{ Extracurricular } \\
\hline Mean & 1.6977 & 1.7284 \\
\hline std. dev. & 0.4718 & 0.4448 \\
\hline weight sum & 172 & 81 \\
\hline Precision & 1 & 1 \\
\hline \multicolumn{3}{|l|}{ Pocket money } \\
\hline Mean & 16882.69 & 16372.55 \\
\hline std. dev. & 7686.855 & 7522.873 \\
\hline weight sum & 172 & 81 \\
\hline precision & 2647.059 & 2647.059 \\
\hline \multicolumn{3}{|c|}{ Duration of study at home } \\
\hline mean & 1.7907 & 1.8395 \\
\hline std. dev. & 0.8086 & 0.8234 \\
\hline weight sum & 172 & 81 \\
\hline precision & 1 & 1 \\
\hline \multicolumn{3}{|c|}{ Social media duration } \\
\hline mean & 1.9942 & 1.963 \\
\hline std. dev. & 1.0702 & 1.0823 \\
\hline
\end{tabular}

\begin{tabular}{|c|c|c|}
\hline \multirow[t]{2}{*}{ Attribute } & \multicolumn{2}{|c|}{ Class } \\
\hline & B & A \\
\hline & $(0.68)$ & $(0.32)$ \\
\hline weight sum & 172 & 81 \\
\hline precision & 1 & 1 \\
\hline \multicolumn{3}{|c|}{ Duration of game online } \\
\hline std. dev. & 0.8716 & 1.2727 \\
\hline weight sum & 172 & 81 \\
\hline precision & 1 & 1 \\
\hline \multicolumn{3}{|l|}{ Total present } \\
\hline mean & 239.222 & 239.6027 \\
\hline std. dev. & 1.7283 & 1.5401 \\
\hline weight sum & 172 & 81 \\
\hline precision & 1.1818 & 1.1818 \\
\hline \multicolumn{3}{|l|}{ Total sick } \\
\hline mean & 0.4622 & 0.0741 \\
\hline std. dev. & 1.2459 & 0.4015 \\
\hline weight sum & 172 & 81 \\
\hline precision & 1.5 & 1.5 \\
\hline \multicolumn{3}{|l|}{ Total permission } \\
\hline mean & 0.189 & 0.2407 \\
\hline std. dev. & 0.7694 & 1.5226 \\
\hline weight sum & 172 & 81 \\
\hline precision & 2.1667 & 2.1667 \\
\hline \multicolumn{3}{|l|}{ Semester 1 grades } \\
\hline mean & 80.5465 & 88.9037 \\
\hline std. dev. & 3.1834 & 3.3689 \\
\hline weight sum & 172 & 81 \\
\hline precision & 1.2 & 1.2 \\
\hline \multicolumn{3}{|l|}{ Semester 2 grades } \\
\hline mean & 82.1618 & 89.7757 \\
\hline std. dev. & 2.513 & 3.248 \\
\hline weight sum & 172 & 81 \\
\hline precision & 1.1667 & 1.1667 \\
\hline
\end{tabular}

Source: (Pattiasina \& Rosiyadi,2020)

The following accuracy results for the Naive Bayes algorithm can be seen in Figure 5.

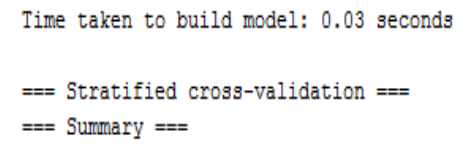

In Figure 6 the accuracy of Naive Bayes is 94.0711, the details of the configuration matrix can be seen in Table 6.

Table 6. Configuration matrix results

\begin{tabular}{cccc}
\hline & True B & True A & $\begin{array}{c}\text { Class } \\
\text { Pecission }\end{array}$ \\
\hline Pred. $B$ & 160 & 12 & $98.20 \%$ \\
Pred. $A$ & 3 & 78 & $86.70 \%$ \\
Class recall & $93.00 \%$ & $96.30 \%$ & \\
\hline Source: (Pattiasina \& Rosiyadi,2020)
\end{tabular}


Following are the results of the ROC graph on the Naive Bayes algorithm on the Weka tools can be seen in Figure 7.

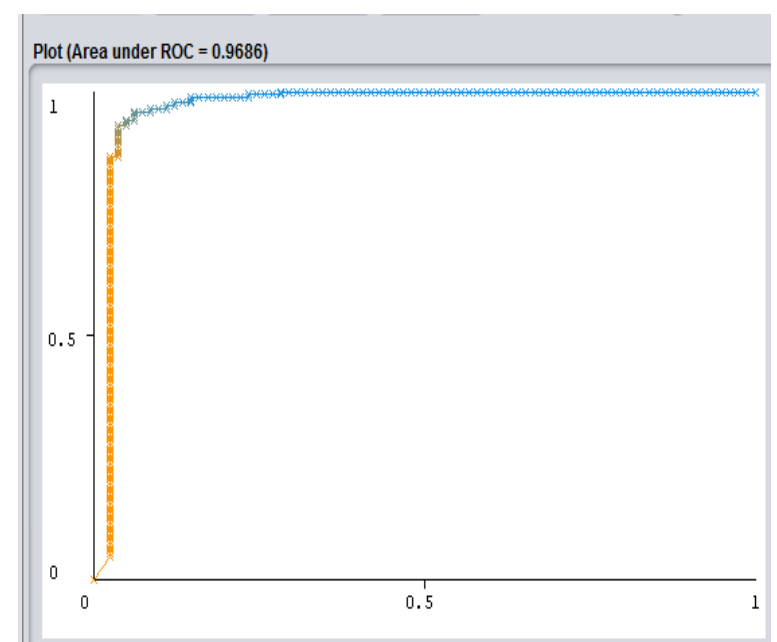

Source: (Pattiasina \& Rosiyadi,2020)

Figure 7. ROC results from naive bayes

The results of ROC processing for naive bayes algorithm is 0.9686 with a diagnosis level of Excellent classification.

\section{K-Nearest Neighbor}

The following results can be seen in the accuracy of Figure 8, using weka tools with k-NN algorithm.

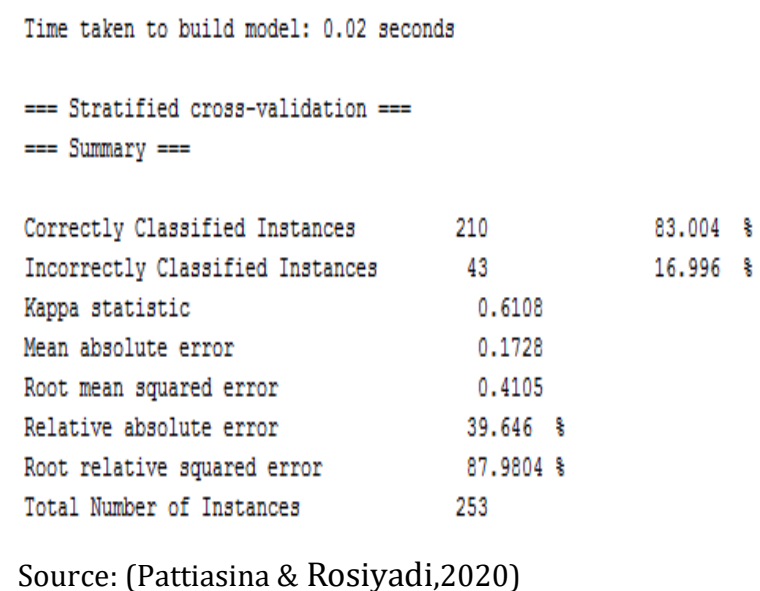

Figure 8. Accuracy of k-NN on weka tools

In Figure 8 the accuracy of the K-NN is 83.004, the detailed configuration matrix can be seen in table 8 .

Table 8. Configuration matrix results

\begin{tabular}{cccc}
\hline \multicolumn{4}{c}{ Table 8. Configuration matrix results } \\
\hline & True B & True A & $\begin{array}{c}\text { Class } \\
\text { Pecission }\end{array}$ \\
\hline Pred. B & 150 & 22 & $87.70 \%$ \\
Pred. A & 21 & 60 & $73.20 \%$ \\
Class recall & $87.20 \%$ & $74.10 \%$ & \\
\hline
\end{tabular}

Source: (Pattiasina \& Rosiyadi,2020)
Following are the results of the ROC graph on the K-NN algorithm on the Weka tools can be seen in Figure 9.

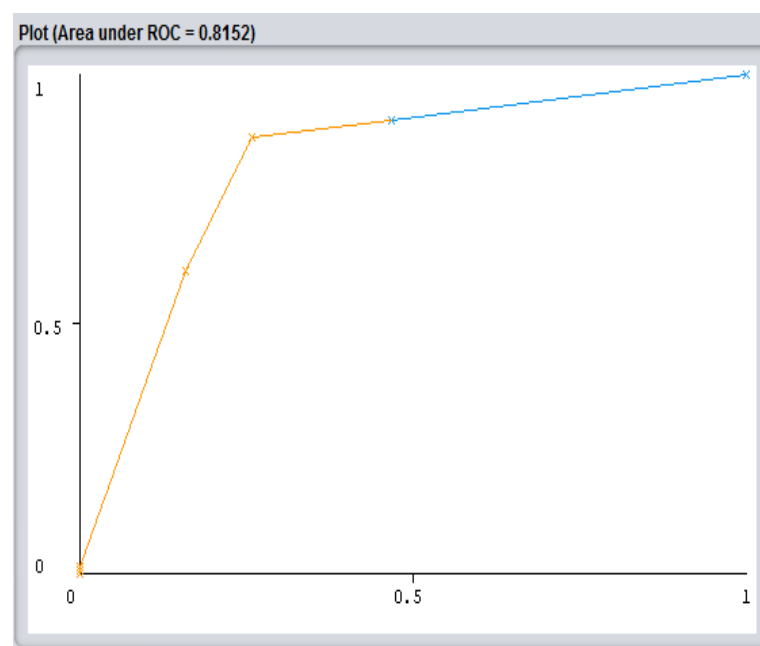

Source: (Pattiasina \& Rosiyadi,2020)

Figure 9. ROC results from K-NN

The results of ROC processing for K-NN algorithm is 0.8152 with a diagnosis level of Good classification.

D. Evaluation of Testing Results

After testing the tools for three algorithms, namely decision tree, naive bayes and k-nearest neighbor, showed different levels of different results. In testing the decision tree algorithm J48 has a higher accuracy that is $99.6047 \%$. Even for other criteria such as Precision and recall, it is still above the two algorithms, namely Naive Bayes and K-NN.

Table 9. Testing DT, NB and k-NN Algorithms

\begin{tabular}{|c|c|c|c|}
\hline & $\begin{array}{c}\text { Decision } \\
\text { Tree }\end{array}$ & Naive Bayes & $K-N N$ \\
\hline Accuracy & $99.6047 \%$ & $94.0711 \%$ & $83.004 \%$ \\
\hline Precission & $99.60 \%$ & $94.50 \%$ & $83.10 \%$ \\
\hline $\begin{array}{l}\text { Recall } \\
\text { ROC }\end{array}$ & $\begin{array}{l}99.60 \% \\
99.46 \%\end{array}$ & $\begin{array}{l}94.10 \% \\
96.86 \%\end{array}$ & $\begin{array}{l}83.00 \% \\
81.52 \%\end{array}$ \\
\hline
\end{tabular}

Source: (Pattiasina \& Rosiyadi,2020)

The following can be seen in Figure 10, a comparison chart of the prediction results of decision tree, naive bayes and K-NN algorithms. 


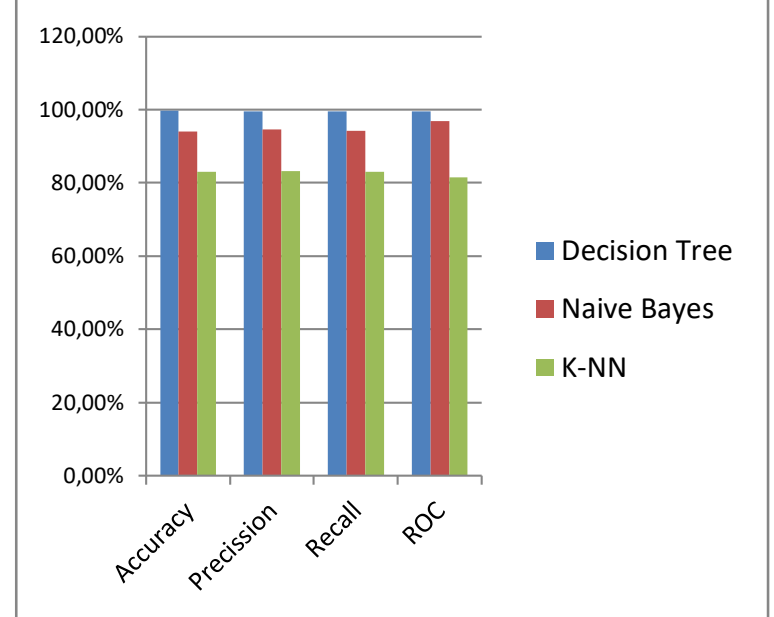

Source: (Pattiasina \& Rosiyadi,2020)

Figure 10. Graph of comparison of algorithm results.

Overall, the J48 decision tree algorithm is one type of algorithm that fits the researcher's data, so that it can obtain a high level of accuracy.

\section{CONCLUSION}

This research was taken from class XI students of SMA Negeri 3 Ambon with a dataset of 253 students. There were fourteen attributes used in the form of age, sex, organization involved in school, extracurricular activities, pocket money, duration of study, duration of social media, duration of playing online games, information on attendance, illness, permission, semester grades one and two. After that, use the Knowledge Discovery in Databes (KDD) data mining method. with the classification algorithm Decision tree J48, Naive Bayes and K-Nearest Neighbor. After the data were processed and labeled, 172 students were classified as good (B) and 81 students as very good (A). For accuracy based on the application Weka can be seen as follows: Accuracy using the Decision Tree Algorithm is $99.6047 \%$. The accuracy using Naive Bayes algorithm is $94.0711 \%$ and K-Nearest Neighbor is $83.004 \%$ so the Decision Tree J48 algorithm has a higher accuracy value than the Naive Bayes algorithm and KNearest Neighbor..

\section{REFERENCES}

Cortez, P., \& Silva, A. (2008). Using data mining to predict secondary school student performance. 15th European Concurrent Engineering Conference 2008, ECEC 2008 - 5th Future Business Technology Conference, FUBUTEC 2008, 2003(2000), 5-12.

Gorunescu, F. (2011). No Title. In Data Mining: Concepts, Models and Techniques. New York:
Springer-Verlag.

Hand, D. J. (2007). Principles of data mining. In Drug Safety (Vol. 30, Issue 7). https://doi.org/10.2165/00002018200730070-00010

Kuntoro, R. K., \& Sudarwanto, R. (2017). Prediction Of Student Performance Using Decision Tree C 4. 5 Algorithm. 214-219.

Peterson, Penelope L; Baker, Eva; McGaw, B. (2010). A Survey on Feature Selection Methods For Imbalanced Datasets. International Encyclopedia of Education. https://www.scholars.northwestern.edu/en/ publications/international-encyclopedia-ofeducation

Rohman, A. (2015). Model Algoritma K-Nearest Neighbor (K-NN) Untuk Prediksi Kelulusan Mahasiswa. Neo Teknika, 1(1), 1-9. https://doi.org/10.1017/CB0978110741532 4.004

Siregar, M., \& Pusphabuana, A. (2017). No Title. In Data Mining: Pengolahan Data Menjadi Informasi dengan Rapidminer. https://books.google.com/books?hl=en\&lr= \&id=rTlmDwAAQBAJ\&oi=fnd\&pg=PR7\&dq= Data+Mining+adalah+serangkaian + proses $+u$ ntuk+menggali+nilai+tambah+berupa+infor masi+yang+selama+ini+tidak+diketahui+sec ara+manual+dari+suatu+basis+data.+Inform asi+yang+dihasilkan+dip

Sugianto, C. A. (2015). Penerapan Teknik Data Mining Untuk Menentukan Hasil Seleksi Masuk Sman 1 Cibeber Untuk Siswa Baru Menggunakan Decision Tree. Tedc, 9, 39-43. 